\title{
Determination of reticulo-rumen and whole-stomach digestion in lactating cows by omasal canal or duodenal sampling
}

\author{
Seppo Ahvenjärvi*, Aila Vanhatalo, Pekka Huhtanen and Tuomo Varvikko \\ Agricultural Research Centre of Finland (MTT), Animal Production Research, FIN-31600 Jokioinen, Finland
}

(Received 19 March 1998 - Revised 10 May 1999 - Accepted 16 July 1999)

\begin{abstract}
Four ruminally and duodenally cannulated multiparous Finnish Ayrshire cows were fed on diets consisting of grass silage $(0.6 \mathrm{~kg} / \mathrm{kg} \mathrm{DM})$ and one of four concentrates: barley, barley + urea, barley + rapeseed meal and barley + rapeseed cake. The objective of the present study was to compare omasal canal and duodenal digesta flows. Values for digesta flow into the omasal canal and duodenum were determined using a triple-marker method based on Co-EDTA, Yb-acetate and indigestible neutral-detergent fibre (NDF) markers. Microbial non- $\mathrm{NH}_{3} \mathrm{~N}$ (NAN) flow was assessed by purine flow. Microbial samples to determine the bacterial purine: $\mathrm{N}$ ratio were harvested from the rumen, omasum and duodenum. Organic matter flow was significantly lower into the omasum than the duodenum, indicating an endogenous organic matter secretion into the abomasum. In contrast, NDF and acid-detergent fibre flows were significantly higher into the omasum indicating digestion of fibre in the omasum. Microbial NAN flows were significantly different $(P<0.001)$ when estimates were based on bacterial samples harvested from different sites. Differences in total NAN, microbial NAN and dietary NAN flows entering the omasal canal and duodenum were non-significant. The results indicated that the omasal sampling technique provides a promising alternative to the duodenal sampling technique to investigate forestomach digestion in dairy cows and offers an alternative means to study rumen $\mathrm{N}$ metabolism.
\end{abstract}

\section{Ruminant: Digestibility: Markers: Omasum}

Physiological studies of digestion in ruminants often require digestive and absorptive processes in the rumen to be quantified. The variety of methods to measure compartmental nutrient flows within the alimentary tract has been limited to the use of cannulas fitted in the omasum, abomasum or duodenum (Faichney, 1993; Harmon \& Richards, 1997). Currently, the most widely used method to measure digesta flow from the rumen relies on sampling through a simple T-cannula fitted either in the proximal duodenum or abomasum (Titgemeyer, 1997). Reports on ruminal digesta outflow measured without post-ruminal cannulation are limited. Punia et al. (1988) estimated the flow of N-fractions from the rumen by obtaining digesta samples from the omasal canal by aspiration through a plastic tube. Huhtanen et al. (1997) developed an omasal sampling technique for obtaining spot samples of ruminal digesta outflow through the reticulo-omasal orifice. The potential advantages of this technique compared with post-ruminal sampling techniques include (1) only ruminal cannulation of animals is needed, (2) substantially less endogenous $\mathrm{N}$ is secreted into the rumen than into the duodenum (Ørskov et al. 1986) and (3) since rumen microbes are not digested in the abomasum, digesta $\mathrm{N}$ flow can be separated into particle- and liquidassociated bacteria, protozoa and soluble and insoluble dietary $\mathrm{N}$ fractions.

The objective of the present experiment was to evaluate the validity of the omasal sampling technique to estimate digesta flow. To produce valuable quantitative information on ruminal digestive processes digesta flow measurements must be both accurate and precise. The precision of measured values can be evaluated in terms of withinanimal variation but assessment of the accuracy requires reliable reference values. In this study, a duodenal sampling technique was used as an alternative method to provide comparative values. However, since omasal and abomasal digestive and absorptive processes may affect the flow of digesta between the omasal canal and the proximal duodenum (Matthews et al. 1996; Faichney et al. 1997) some differences may be expected. Comparative effects of the different dietary treatments used in this study are documented in another publication (Ahvenjärvi et al. 1999).

\footnotetext{
Abbreviations: ADF, acid-detergent fibre; FP, fluid phase; LP, large-particle phase; NAN, non-ammonia nitrogen; NDF, neutral-detergent fibre; OM, organic matter; SP, small-particle phase.

* Corresponding author: Seppo Ahvenjärvi, fax +358 34188 3661, email seppo.ahvenjarvi@mtt.fi
} 


\section{Materials and methods}

\section{Experimental procedures}

Four multiparous dairy cows fitted with $100 \mathrm{~mm}$ i.d. ruminal cannulas and $\mathrm{T}$-shaped cannulas in the duodenum proximal to the pancreatic duct were used in a $4 \times 4$ Latin-square experiment. Cows were fed on silage $(0.60 \mathrm{~kg} / \mathrm{kg}$ DM) supplemented $(0.40 \mathrm{~kg} / \mathrm{kg} \mathrm{DM})$ with either barley, barley + urea, barley + solvent-extracted rapeseed meal or barley + moist-heat-treated rapeseed cake. Silage was prepared from a first-cut sward containing timothy (Phleum pratense), meadow fescue (Festuca pratensis) and red clover (Trifolium pratense). Herbage was wilted after cutting, then harvested using a precision-chop forage harvester and ensiled with 5 litres/tonne of a formic-acid-based additive. Barley-rapeseed meal and barley-rapeseed cake treatments were not entirely isonitrogenous, since equal quantities of rapeseed meal and rapeseed cake were included in the concentrate portion $(0 \cdot 25 \mathrm{~kg} / \mathrm{kg} \mathrm{DM})$. Urea content of the barley + urea diet was adjusted so that the diet was isonitrogenous with respect to the mean $\mathrm{N}$ content of the barley-rapeseed meal and barley-rapeseed cake treatments. Each animal was also offered $300 \mathrm{~g} / \mathrm{d}$ of a commercial mineral mixture (ViherMinera, Suomen Rehu Oy, Helsinki, Finland). Intake of feed ingredients is shown in Table 1, while chemical composition is presented in Table 2. Cows averaged 74 (SD 22.3) d in milk and 560 (SD 68.5) $\mathrm{kg}$ live weight at the beginning of the study. Each experimental period lasted $21 \mathrm{~d}$ consisting of a $16 \mathrm{~d}$ adaptation period and a $5 \mathrm{~d}$ sample collection period.

Cows had free access to silage during adaptation periods, but during sample collection periods intake was restricted to 0.95 of that during the adaptation period. Intake restriction was used to minimize between- and within-day variations in intake during intensive sampling. Diets were offered twice daily at 06.00 and 18.00 hours, with cows being milked at 07.00 and 17.00 hours. Intake and milk production were recorded daily. Cows were weighed at the beginning and the end of the study.

Omasal canal and duodenal digesta flows were assessed using indigestible neutral-detergent fibre (NDF), LiCoEDTA (Udén et al. 1980) and Yb-acetate as markers. LiCoEDTA ( $12 \mathrm{~g} / \mathrm{d}$ per cow) and $\mathrm{Yb}$-acetate $(3.7$ to $4.2 \mathrm{~g} / \mathrm{d}$ per cow) were dissolved in 6 litres distilled water and infused continuously into the rumen. Continuous infusion of $\mathrm{Co}$ and

Table 1. Intake of feed ingredients (kg DM/d) by cows fed on different diets

\begin{tabular}{lcccc}
\hline & \multicolumn{4}{c}{ Diet } \\
\cline { 2 - 5 } & B & BU & BRM & BRC \\
\hline Silage & 8.47 & 8.46 & 8.65 & 8.89 \\
Barley & 5.70 & 5.22 & 4.50 & 4.51 \\
Rapeseed meal & & & 1.54 & 1.50 \\
Rapeseed cake & & 0.128 & & 0.293 \\
Urea & 0.277 & 0.257 & 0.292 & 0.29 \\
Minerals & 14.4 & 14.1 & 15.0 & 15.2 \\
Total &
\end{tabular}

B, barley; BU, barley + urea; BRM, barley+solvent-extracted rapeseed meal; $\mathrm{BRC}$, barley + moist-heat-treated rapeseed cake.
Table 2. Chemical composition of experimental feeds ( $\mathrm{g} / \mathrm{kg} \mathrm{DM})$

\begin{tabular}{lcccc}
\hline & Silage* $^{*}$ & Barley & $\begin{array}{c}\text { Rapeseed } \\
\text { meal }\end{array}$ & $\begin{array}{c}\text { Rapeseed } \\
\text { cake }\end{array}$ \\
\hline DM $(\mathrm{g} / \mathrm{kg})$ & 211 & 872 & 897 & 910 \\
Ash & 78 & 23 & 73 & 75 \\
Nitrogen & $22 \cdot 7$ & $17 \cdot 9$ & $64 \cdot 9$ & $56 \cdot 2$ \\
NDF & 638 & 260 & 268 & 290 \\
ADF & 385 & 65 & 193 & 198 \\
Ether extract & $\mathrm{ND}$ & $\mathrm{ND}$ & 39 & 102 \\
\hline
\end{tabular}

NDF, neutral-detergent fibre; ADF, acid-detergent fibre; ND, not determined. * Silage fermentation quality: $\mathrm{pH} 4.13$; in DM $(\mathrm{g} / \mathrm{kg})$ : lactic acid 39.1, acetic acid 20.8 , propionic acid 0.5 , butyric acid 2.5 , reducing sugars 24.9 ; in total $\mathrm{N}$ $(\mathrm{g} / \mathrm{kg})$ : soluble $\mathrm{N} 490$, ammonium N 58 .

$\mathrm{Yb}$ was started on day 13. To determine digesta flow into the omasal canal and duodenum, $400 \mathrm{ml}$ spot omasal canal and duodenal samples were collected three times daily at $4 \mathrm{~h}$ intervals on days 17-20. Sampling started at 07.00 hours and advanced $1 \mathrm{~h}$ every day to cover a $12 \mathrm{~h}$ period, which was considered representative of the entire feeding cycle. Samples were collected from the omasal canal using the system described by Huhtanen et al. (1997), with the exception that the three-way stainless steel ball valve controlling alternating pressure and vacuum in the omasal sampling device was replaced by solenoid valves controlled by an adjustable relay. In addition, the tube of the sampling device was larger (14 v. $9.5 \mathrm{~mm}$ i.d.). Omasal canal and duodenal spot samples from each cow were pooled on an equal volume basis over the sampling times to provide composite omasal canal and duodenal samples. Pooled samples were stored frozen at $-20^{\circ}$. Once thawed at room temperature, samples were separated into three different phases as follows. Whole digesta was first squeezed through one layer of cheesecloth. Solids retained on the cheesecloth were defined as the large-particle phase (LP). The filtrate was separated into small particle (SP) and fluid phases (FP) by centrifugation at $10000 \mathrm{~g}$ for $15 \mathrm{~min}$ and removing the supernatant fraction by aspiration. LP, SP and FP were frozen and freeze-dried for chemical analysis.

Feed digestibility was determined by total faecal collection on days 18-21. Urine was separated from faeces by means of a light harness attached to the vulva of each cow and a flexible tube attached to a container residing behind the animal. On day $21,500 \mathrm{ml}$ samples of ruminal and omasal canal and $250 \mathrm{ml}$ duodenal digesta were collected immediately before feeding and at 4 and $8 \mathrm{~h}$ post-feeding. Omasal canal and duodenal samples were collected using the method previously described. Ruminal samples were evacuated by a vacuum pump using a tube with holes on the side inserted into the rumen via the rumen cannula. This procedure allowed some particle flow into the sample. Samples were chilled on ice immediately after collection. Ruminal and omasal canal samples were divided into two $250 \mathrm{ml}$ subsamples.

Bacterial samples were prepared from ruminal, omasal canal and duodenal samples by differential centrifugation. Samples were first centrifuged at $200 \mathrm{~g}$ for $7 \mathrm{~min}$ and the supernatant fraction was decanted through two layers of cheesecloth. The pellet was then suspended in $50 \mathrm{ml} \mathrm{NaCl}$ solution $(9 \mathrm{~g} / \mathrm{l})$ and agitated for $10 \mathrm{~s}$ (Ultra-Turrax, model T-25, Janke \& Kunkel GmbH \& Co KG, Staufen, Germany) 
to detach bacteria adhering to particles. This suspension was further centrifuged at $200 \mathrm{~g}$ for $7 \mathrm{~min}$. The supernatant fraction was decanted through two layers of cheesecloth and pooled with the supernatant fraction from the first centrifugation. The supernatant fraction was centrifuged again at $200 \mathrm{~g}$ for $7 \mathrm{~min}$. Following centrifugation, the supernatant fraction was decanted and centrifuged at $10000 \mathrm{~g}$ for $30 \mathrm{~min}$ to sediment bacteria. The bacterial pellet was subsequently suspended in distilled water and freeze-dried.

\section{Chemical analysis}

Feed and faecal DM values were determined by oven-drying at $105^{\circ}$ for $18 \mathrm{~h}$. Silage DM was corrected for the loss of volatiles (Huida et al. 1986). Silage and digesta samples were freeze-dried for analysis. Organic matter (OM) was determined by ashing at $600^{\circ}$ for $18 \mathrm{~h}$. NDF and aciddetergent fibre (ADF) were determined according to Van Soest et al. (1991) and Robertson \& Van Soest (1981) respectively. Difficulties in filtering after refluxing in NDF-solution were encountered during NDF analysis of omasal SP. This resulted in an increase in SP NDF content, and consequently increased the NDF: ADF ratio in SP in relation to that of LP $(8.5 v .2 .0)$. Therefore, the NDF content in SP was estimated from the ADF content assuming the same NDF: ADF ratio of LP. Silage and ruminal fluid volatile fatty acids were measured according to Huhtanen et al. (1998). Silage was analysed for lactic acid (Barker \& Summerson, 1941) and water-soluble carbohydrates (Somogyi, 1945). $\mathrm{NH}_{3}-\mathrm{N}$ concentrations in silage and digesta were analysed according to McCullough (1967). NDF- and ADF-associated $\mathrm{N}$ contents were assessed according to Licitra et al. (1996). Purines in bacterial samples and digesta, expressed as yeast RNA equivalents, were determined according to the method of Zinn \& Owens (1986). Crude protein content of feeds, dried digesta and bacterial samples was determined using a Dumas-type $\mathrm{N}$ analyser (Leco FP-428; Leco Corporation, St Joseph, MI, USA). The soluble $\mathrm{N}$ content of silage and the $\mathrm{N}$ content of undried silage and faecal samples were analysed by the Kjeldahl method. Co and $\mathrm{Yb}$, prepared as described by Williams et al. (1962), were analysed by atomic absorption spectrophotometry. Indigestible NDF was determined in LP, SP and faeces but not in FP since particles were absent in this phase. Samples were weighed in duplicate $(4 \mathrm{~g})$ into $6 \mu \mathrm{m}$ pore size nylon bags, incubated in the rumen of two cows for $12 \mathrm{~d}$, then rinsed in a household washing machine, incubated for $60 \mathrm{~min}$ in boiling NDF solution, rinsed again and dried to a constant weight at $60^{\circ}$. Since indigestible residue was not ashed after NDF extraction, indigestible NDF contains inorganic matter, unlike NDF.

\section{Calculations}

Digesta flows into the omasum and duodenum were calculated using a triple-marker method (France \& Siddons, 1986). Residual $\mathrm{NH}_{3}$ in freeze-dried omasal and duodenal samples was subtracted from total $\mathrm{N}$ to calculate non- $\mathrm{NH}_{3} \mathrm{~N}$ (NAN) content. Freeze-dried duodenal digesta samples were devoid of residual volatile fatty acids but omasal samples, which had a higher $\mathrm{pH}$, contained substantial amounts. Therefore, freeze-dried FP samples were analysed for volatile fatty acid concentration and omasal OM flow was corrected for residual volatile fatty acids. Microbial NAN flows into the omasal canal and duodenum were calculated using purine bases as a marker. Endogenous NAN flow was calculated according to Ørskov et al. (1986) assuming 0.085 and $0.195 \mathrm{~g} \quad \mathrm{NAN} / \mathrm{kg}$ live weight ${ }^{0.75}$ per animal per $d$ entering the omasal canal and duodenum respectively.

Microbial NAN flow $(\mathrm{g} / \mathrm{d})=$

NAN in bacteria $(\mathrm{g} / \mathrm{g}) /$ purines in bacteria $(\mathrm{g} / \mathrm{g})$

$\times$ purine flow $(\mathrm{g} / \mathrm{d})$.

Total NAN flow $(\mathrm{g} / \mathrm{d})=$ microbial NAN flow $(\mathrm{g} / \mathrm{d})$

+ dietary NAN flow $(\mathrm{g} / \mathrm{d})+$ endogenous

NAN flow $(\mathrm{g} / \mathrm{d})$.

Marker recoveries in faeces averaged 1.03, 1.01 and $0.98 \mathrm{~g} / \mathrm{g}$ for indigestible NDF, $\mathrm{Yb}$ and Co respectively. However, estimates of $\mathrm{Yb}$ and Co flows into the omasal canal and duodenum were based on their appearance in faeces. Co flow beyond the sampling site was not corrected for potential absorption from the digestive tract.

\section{Statistical analysis}

The effect of digesta sampling site was assessed by the following split-plot model using the general linear models procedure within SAS (version 6, 1987; Statistical Analysis Systems Institute Inc., Cary, NC, USA).

$$
\begin{aligned}
\mathrm{Y}_{\mathrm{ijkl}}= & \mu+\mathrm{A}_{\mathrm{i}}+\mathrm{P}_{\mathrm{j}}+\mathrm{D}_{\mathrm{k}}+\mathrm{e}_{\mathrm{ijk}}+\mathrm{S}_{1} \\
& +\mathrm{AS}_{\mathrm{il}}+\mathrm{PS}_{\mathrm{jl}}+\mathrm{DS}_{\mathrm{kl}}+\mathrm{e}_{\mathrm{ijk} \mathrm{kl}},
\end{aligned}
$$

where A, P, D and S are animal, period, diet and sampling site effects. Interactions between treatment, digesta sampling site and bacterial sampling site were assessed by the following split-split-plot model:

$$
\begin{aligned}
\mathrm{Y}_{\mathrm{ijklm}}= & \mu+\mathrm{A}_{\mathrm{i}}+\mathrm{P}_{\mathrm{j}}+\mathrm{D}_{\mathrm{k}}+\mathrm{e}_{\mathrm{ijk}}+\mathrm{S}_{1}+(\mathrm{AS})_{\mathrm{il}}+(\mathrm{PS})_{\mathrm{jl}} \\
& +(\mathrm{DS})_{\mathrm{kl}}+\mathrm{e}_{\mathrm{ijkl}}+\mathrm{B}_{\mathrm{m}}+(\mathrm{AB})_{\mathrm{im}}+(\mathrm{PB})_{\mathrm{jm}} \\
& +(\mathrm{DB})_{\mathrm{km}}+\mathrm{e}_{\mathrm{ijkm}}+(\mathrm{SB})_{\mathrm{lm}}+(\mathrm{ASB})_{\mathrm{ilm}} \\
& +(\mathrm{PSB})_{\mathrm{jlm}}+(\mathrm{DSB})_{\mathrm{klm}}+\mathrm{e}_{\mathrm{ijklm}},
\end{aligned}
$$

where $\mathrm{A}, \mathrm{P}, \mathrm{D}, \mathrm{S}$ and $\mathrm{B}$ are animal, period, diet, digesta sampling site and bacterial sampling site effects. The significance of pairwise differences between means was evaluated using Tukey's test in SAS (1987; Statistical Analysis Systems Institute Inc.). CV within animal were calculated as the square root of the mean square $\left(\mathrm{e}_{\mathrm{ijk}}\right)$ divided by the mean. Standard error of the mean for each digesta sampling site was calculated as the square root of the mean square $\left(\mathrm{e}_{\mathrm{ijk}}\right)$ divided by the square root of the number of observations $(n)$ per mean. Standard error of the mean for each bacterial sampling site was calculated as the square root of the mean square $\left(\mathrm{e}_{\mathrm{ijk} k \mathrm{~m}}\right)$ divided by the square root of the number of observations $(n)$ per mean. 
Table 3. Intake and flow of digesta chemical components $(\mathrm{g} / \mathrm{d})$ into the omasal canal and duodenum of cows

(Mean values for fifteen observations, with pooled standard errors)

\begin{tabular}{lccc}
\hline & OM & NDF & ADF \\
\hline Intake & 13890 & 6818 & 3670 \\
Omasal canal flow & $6948^{\mathrm{a}}$ & $3174^{\mathrm{a}}$ & $1609^{\mathrm{a}}$ \\
Duodenal flow & $7469^{\mathrm{b}}$ & $2872^{\mathrm{b}}$ & $1478^{\mathrm{b}}$ \\
$\quad 12$ & 43.0 & 23.4 \\
SEM & 112 & 2749 & 1440 \\
$\quad$ faeces & 4102 & 61.4 & 30.5 \\
Apparent digestibility in the & 89 & & \\
$\quad$ Reticulo-rumen & & $0.538^{\mathrm{a}}$ & $0.563^{\mathrm{a}}$ \\
$\quad$ Whole stomach† & $0.504^{\mathrm{a}}$ & $0.582^{\mathrm{b}}$ & $0.600^{\mathrm{b}}$ \\
$\quad$ SEM & $0.466^{\mathrm{b}}$ & 0.0065 & 0.0072 \\
Total digestibility & 0.0074 & 0.599 & 0.610 \\
$\quad$ SEM & 0.706 & 0.0088 & 0.0086 \\
\hline
\end{tabular}

OM, organic matter; NDF, neutral-detergent fibre; ADF, acid-detergent fibre.

${ }^{\mathrm{a}, \mathrm{b}}$ Mean values within a column with different superscript letters were significantly different, $P<$ 0.05 .

*Based on omasal canal flow.

†Based on duodenal flow.

\section{Results}

\section{Sample quality}

In period 2, one cow stopped eating during the collection period and consequently one observation was lost. The compressible ring of the omasal sampling device was found to be stretching the reticulo-omasal orifice and probably accounts for this lack of appetite. According to reconstitution factors the proportions of different phases (g/g DM) in pooled omasal canal spot samples and in calculated true digesta were 0.36 and 0.54 for LP, 0.25 and 0.20 for SP, 0.39 and 0.26 for FP respectively. The proportions of different phases in pooled duodenal spot samples and in calculated true digesta were 0.66 and 0.65 for LP, 0.07 and 0.10 for SP, 0.26 and 0.25 for FP respectively.

\section{Organic matter and fibre flow}

Interactions between diet and digesta sampling sites (omasal canal and duodenum) were not significant $(P>0.05)$ for $\mathrm{OM}, \mathrm{NDF}$ and ADF flows. OM flow was lower $(P=0.033)$ into the omasal canal than the duodenum (Table 3 ). In contrast, ash flow was higher $(P<0 \cdot 001)$ into the omasal canal $(2211 v .1913 \mathrm{~g} / \mathrm{d}$, SEM $26 \cdot 2 \mathrm{~g} / \mathrm{d})$. Within each sampling site, the $\mathrm{CV}$ in $\mathrm{OM}$ flow was similar for the omasal canal and duodenum $(0.065$ v. 0.067$)$. The correlation coefficient between omasal canal and duodenal OM flow was 0.92 (Fig. 1).

NDF flow was $302 \mathrm{~g} / \mathrm{d}$ higher $(P=0.005)$ into the omasal canal than the duodenum (Table 3 ). Of this difference, hemicellulose-associated protein $(\mathrm{N} \times 6.25)$ accounted for $85 \mathrm{~g} / \mathrm{d}$, protein-free hemicellulose $86 \mathrm{~g} / \mathrm{d}$, and ADF $131 \mathrm{~g} / \mathrm{d}$. Relative proportions of NDF digested in the rumen, omasal canal and intestines were $0.90,0.07$ and 0.03 respectively. The CV for NDF flow within each sampling site was slightly higher for the omasal canal compared with the duodenum $(0.084$ v. 0.070). The correlation coefficient between the omasal canal and duodenal NDF flow was 0.93 (Fig. 2).

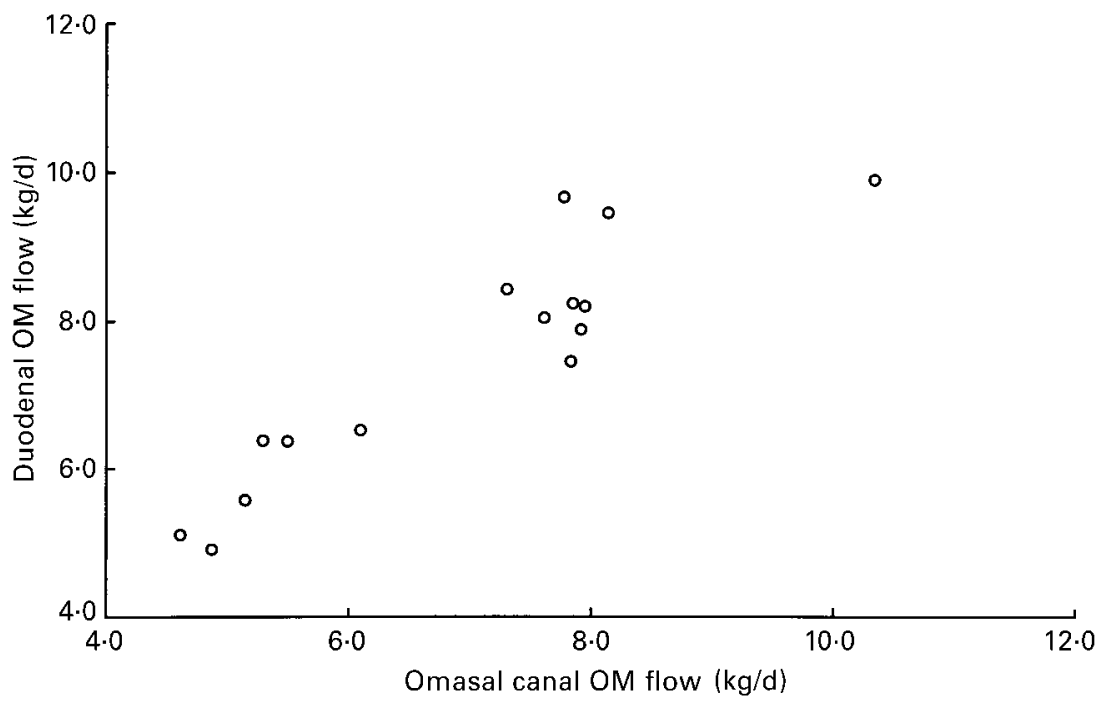

Fig. 1. Relationship between flows of organic matter (OM) into the omasal canal and duodenum (kg/d) in cows (r 0.92). 


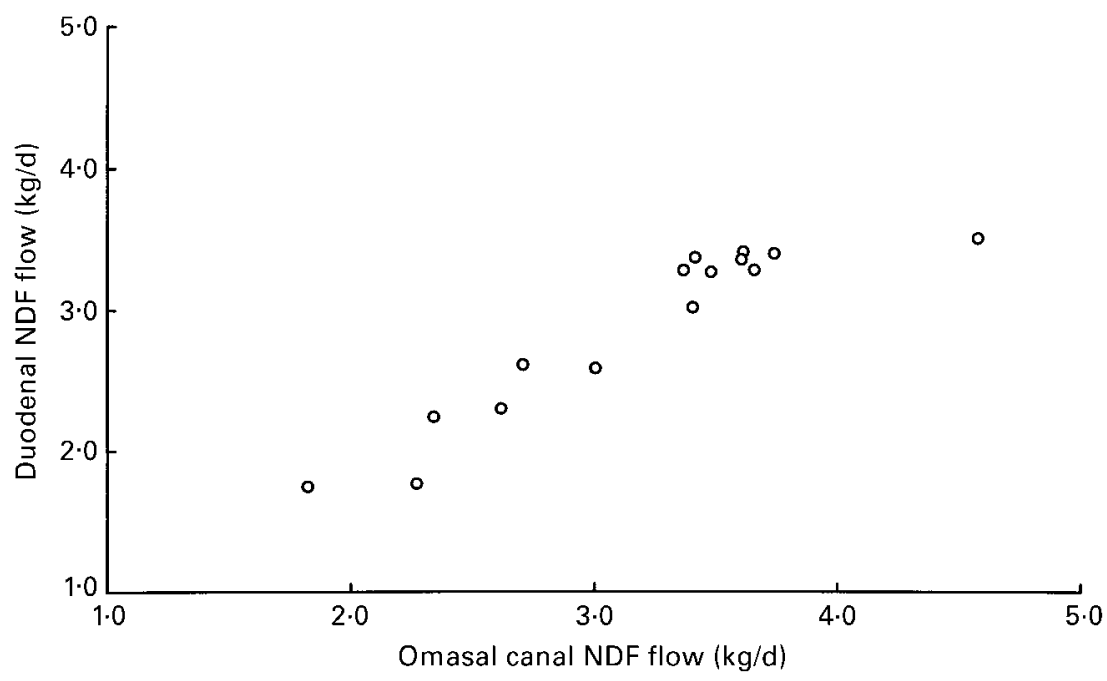

Fig. 2. Relationship between flows of neutral-detergent fibre (NDF) into the omasal canal and duodenum $(\mathrm{kg} / \mathrm{d})$ in cows $(r 0.93)$.

ADF flow was higher $(P=0 \cdot 012)$ into the omasal canal than the duodenum (Table 3 ). The proportions of ADF digested in the rumen, omasal canal and intestines were $0.92,0.06$ and 0.02 respectively. CV in ADF flow within each sampling site was slightly higher for the omasal canal than the duodenum $(0 \cdot 087 v .0 \cdot 075)$. The correlation coefficient between the omasal canal and duodenal ADF flows was 0.96 (Fig. 3).

\section{Nitrogen fractions}

Three-way interactions between diet, sampling site and bacterial sampling site for microbial NAN flow, dietary NAN flow or true $\mathrm{N}$ digestibility were non-significant. Twoway interactions between diet and bacterial sampling site in microbial or dietary NAN flow or true $\mathrm{N}$ digestibility were also non-significant.
Bacterial samples collected from the rumen, omasal canal and duodenum had significantly different $(P<0.001)$ purine $\mathrm{N}$ ratios. Bacterial purine content was highest in bacteria harvested in the rumen and lowest in those collected from the duodenum. Purine content of bacteria from the omasal canal was intermediate (Table 4). Differences in bacterial purine: $\mathrm{N}$ ratios between harvesting sites resulted in significant differences $(P<0.001)$ in microbial and dietary NAN flow and true rumen $\mathrm{N}$ digestibility. Microbial NAN flow was lowest based on the purine content of bacteria harvested from the rumen and increased for samples harvested from the omasal canal and duodenum (Table 4). CV in calculated microbial NAN flow were similar when based on bacteria collected from the rumen (0.070), omasal canal (0.071) and duodenum (0.076) respectively.

To avoid confounding effects of microbial composition due to harvesting method, omasal canal and duodenal

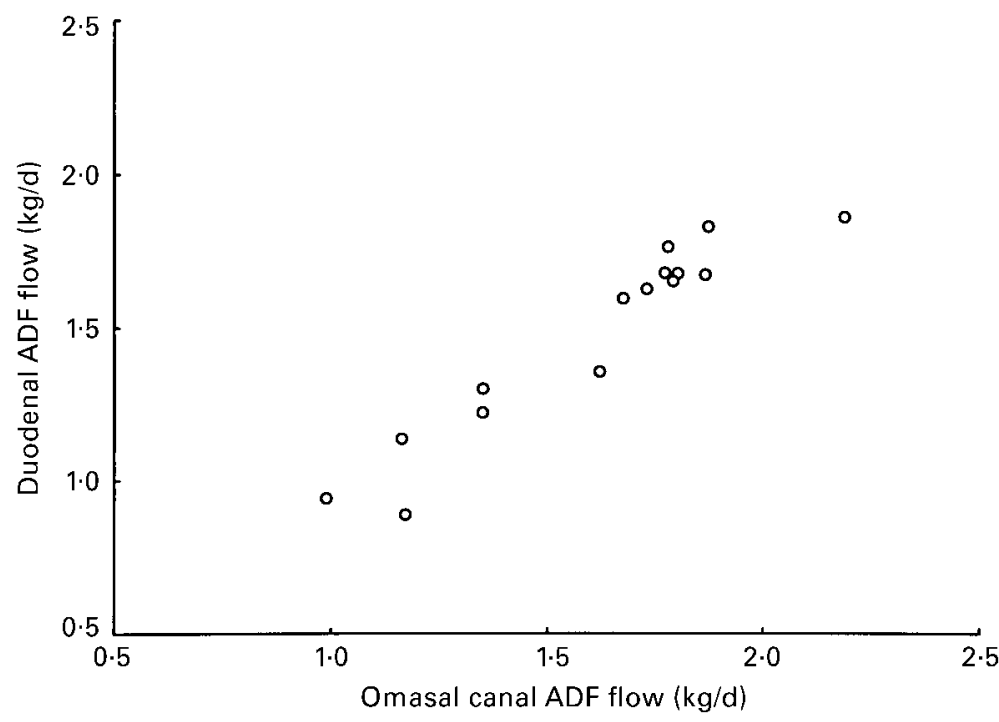

Fig. 3. Relationship between flows of acid-detergent fibre (ADF) into the omasal canal and duodenum $(\mathrm{kg} / \mathrm{d})$ in cows (r 0.96). 
Table 4. Effect of bacterial sampling site on microbial non-ammonia nitrogen flow $(\mathrm{g} / \mathrm{d})$ and bacterial purine: $\mathrm{N}$ value $(\mathrm{g} / \mathrm{g})$ in cows

(Mean values with their pooled standard errors)

\begin{tabular}{lccccc}
\hline & \multicolumn{4}{c}{ Bacterial sampling site } \\
\cline { 2 - 6 } & Rumen & Omasum & Duodenum & SEM & $n$ \\
\hline Purines : N in bacteria* & $1.18^{\mathrm{a}}$ & $1.12^{\mathrm{b}}$ & $1.02^{\mathrm{c}}$ & 0.008 & 15 \\
Microbial NAN flow & $171^{\mathrm{a}}$ & $181^{\mathrm{b}}$ & $200^{\mathrm{c}}$ & 0.3 & 30 \\
Dietary NAN flow & $134^{\mathrm{a}}$ & $124^{\mathrm{b}}$ & $105^{\mathrm{c}}$ & 0.3 & 30 \\
N truly digested in the forestomachs & $0.622^{\mathrm{a}}$ & $0.651^{\mathrm{b}}$ & $0.702^{\mathrm{c}}$ & 0.0009 & 30 \\
\hline
\end{tabular}

NAN, non-ammonia nitrogen.

${ }^{a, b, c}$ Mean values within a row with unlike superscript letters were significantly different, $P<0.05$.

* Purine concentration expressed as yeast RNA equivalents.

$\mathrm{N}$-fraction flows were compared based on omasal canal microbial composition. Interactions between diet and digesta sampling site were non-significant for microbial NAN $(P=0.95)$, or total NAN flow $(P=0.29)$. Interactions between these factors were also non-significant for the apparent $(P=0.86)$ and true efficiencies of microbial $\mathrm{N}$ synthesis $(P=0.93)$. However, interaction between diet and sampling site was significant for dietary NAN flow $(P=$ $0.018)$ and true ruminal digestibility of $\mathrm{N}(P=0.036)$. Compared with the control diet, rapeseed feeds increased omasal canal dietary NAN flow by $46 \mathrm{~g} / \mathrm{d}$, while duodenal dietary NAN flow increased by only $25 \mathrm{~g} / \mathrm{d}$. True ruminal $\mathrm{N}$ digestibilities determined in the omasal canal were $0.67 v$. 0.62 for the control compared with diets supplemented with rapeseed feed respectively. Corresponding values determined in the duodenum were 0.62 and 0.64 respectively.
Total NAN flows into the omasal canal and duodenum ( 319 v. $324 \mathrm{~g} / \mathrm{d}$, SEM $3 \cdot 1 \mathrm{~g} / \mathrm{d})$ were similar $(P=0 \cdot 35)$. Microbial NAN flow tended to be higher $(P=0.087)$ into the omasal canal than duodenum (Table 5). Sampling site had no effect on the apparent or true efficiency of microbial $\mathrm{N}$ synthesis $(P=0.91$ and $P=0.81$ respectively). Since 9.8 and $22.4 \mathrm{~g}$ endogenous NAN/d were estimated to flow into the omasal canal and duodenum respectively, the residual NAN assigned to dietary NAN flow was similar for the omasum and duodenum $(P=0 \cdot 27)$.

The CV within each digesta sampling site was lower for the omasal canal than the duodenum in total NAN flow (0.046 v. 0.074) and microbial NAN flow (0.092 v. $0 \cdot 117)$, but higher in dietary NAN flow $(0 \cdot 101 v .0 \cdot 085)$. The correlation coefficient between omasal canal and duodenal microbial NAN flow was 0.94 (Fig. 4) and

Table 5. Effect of bacterial sampling site on microbial non-ammonia nitrogen (NAN) and dietary non-ammonia nitrogen flows into the omasal canal and duodenum $(\mathrm{g} / \mathrm{d})$ and on true nitrogen digestion determined in the omasal canal and duodenum in cows

(Mean values for fifteen observations, with pooled standard errors)

\begin{tabular}{|c|c|c|c|}
\hline & \multicolumn{3}{|c|}{ Bacterial sampling site } \\
\hline & Rumen & Omasum & Duodenum \\
\hline \multicolumn{4}{|l|}{ Microbial NAN flow } \\
\hline Omasal canal & 175 & 186 & 205 \\
\hline Duodenum & 166 & 176 & 195 \\
\hline SEM & $3 \cdot 1$ & $3 \cdot 3$ & 3.9 \\
\hline \multicolumn{4}{|c|}{$\begin{array}{l}\text { Microbial N synthesis } \\
(\mathrm{g} / \mathrm{kg} \text { OMADR })\end{array}$} \\
\hline Omasal canal & $25 \cdot 6$ & $27 \cdot 2$ & $30 \cdot 0$ \\
\hline Duodenum & $26 \cdot 1$ & $27 \cdot 6$ & $30 \cdot 6$ \\
\hline $\begin{array}{c}\text { SEM } \\
(\mathrm{g} / \mathrm{kg} \mathrm{OMTDR})\end{array}$ & \multicolumn{2}{|c|}{ (g/kg OMTDR) } & $1 \cdot 13$ \\
\hline Omasal canal & $19 \cdot 8$ & $20 \cdot 6$ & $22 \cdot 2$ \\
\hline Duodenum & $20 \cdot 1$ & $21 \cdot 0$ & $22 \cdot 6$ \\
\hline SEM & 0.50 & 0.51 & 0.55 \\
\hline \multicolumn{4}{|l|}{ Dietary NAN flow } \\
\hline Omasal canal & 133 & 123 & 104 \\
\hline Duodenum & 135 & 126 & 107 \\
\hline SEM & 1.2 & $1 \cdot 3$ & 1.6 \\
\hline \multicolumn{4}{|c|}{ True digestibility of $\mathrm{N}$ in the } \\
\hline Reticulo-rumen & 0.626 & 0.656 & 0.708 \\
\hline Whole stomach & 0.618 & 0.646 & 0.696 \\
\hline SEM & 0.0044 & 0.0047 & 0.0059 \\
\hline
\end{tabular}

OMADR, organic matter apparently digested in the rumen; OMTDR, organic matter truly digested in the rumen. 


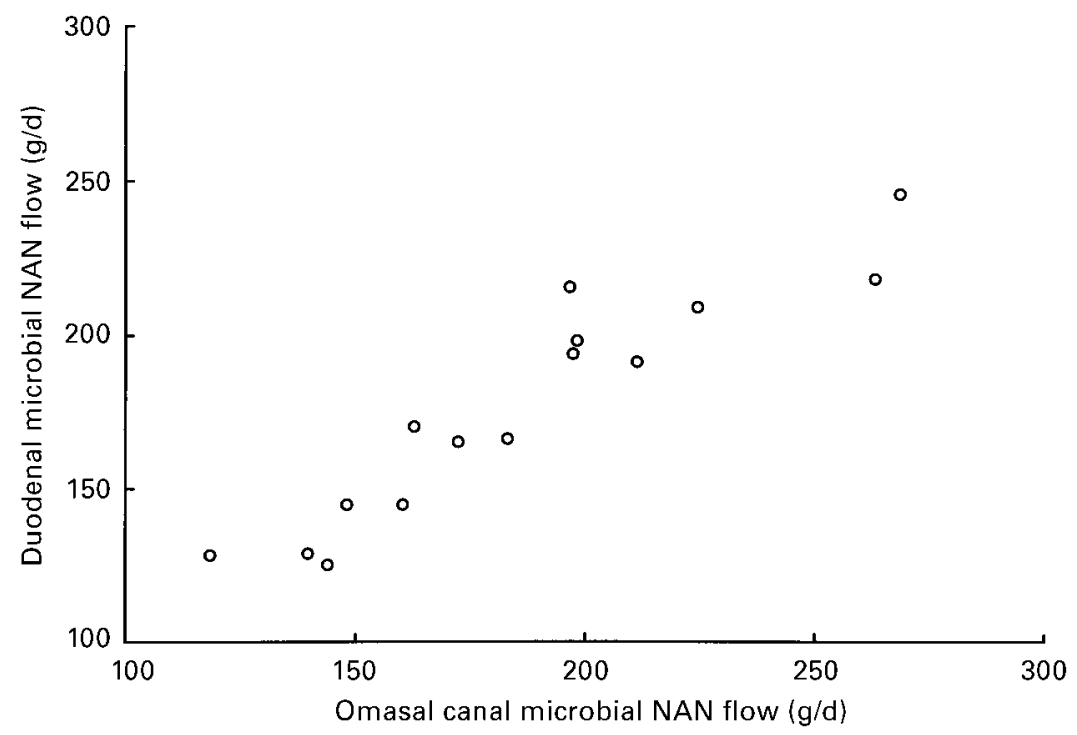

Fig. 4. Relationship between flows of microbial non-ammonia nitrogen (NAN) into the omasal canal and duodenum $(\mathrm{g} / \mathrm{d})$ in cows $(r 0.94)$.

between omasal canal and duodenal dietary NAN flow 0.79 (Fig. 5).

\section{Discussion}

\section{Sample quality}

When omasal canal and duodenal digesta flows are compared some differences might be expected due to omasal and abomasal digestive processes. Correlation coefficients between omasal canal and duodenal flows reflected sampling errors, precision of chemical analysis and the extent of endogenous secretions and metabolism of nutrients between sampling sites. Generally, observed variations in nutrient flows into the omasal canal or duodenum were relatively similar for each site and were acceptable compared with published values (Titgemeyer, 1997). Since a small proportion of Cr-EDTA has been shown to be absorbed from the digestive tract and excreted in urine, correction for this absorption has been suggested (Faichney, 1975b). In the present study, daily faecal outputs of markers were assumed to represent the true quantity of markers passing

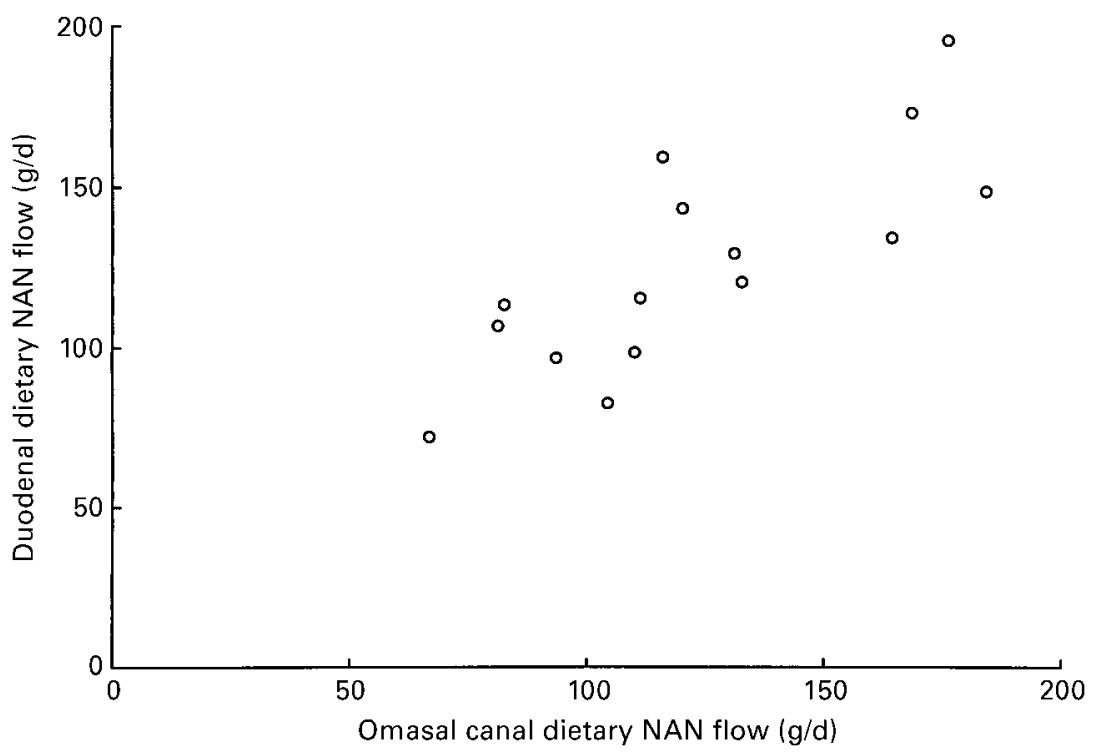

Fig. 5. Relationship between flows of dietary non-ammonia nitrogen (NAN) into the omasal canal and duodenum $(\mathrm{g} / \mathrm{d})$ in cows $(r 0.79)$. 
the sampling sites. However, if post-ruminal marker absorption occurred, the calculated marker dose should have been corrected for the quantity of the marker absorbed posterior to the sampling site. If 0.04 of Co-EDTA had been excreted in urine (Faichney, 1975a; Siddons et al. 1985), and assuming that Co-EDTA absorption is related to mean sectional retention time (Faichney, 1975a) and that the retention times are similar in the rumen and postruminal tract (Huhtanen \& Kukkonen, 1995), in the current study the daily dose of Co would have been underestimated by 0.02 units. This would have resulted in a 0.01 unit underestimate of DM flow, but flows of other chemical components would have remained essentially unchanged.

The composition of omasal canal samples deviated more from calculated true digesta than that in duodenal samples. Large deviations from the true composition may seriously challenge marker systems used to correct for unrepresentative sampling. Theoretically, non-uniform distribution of a marker in digesta particle phase in combination with an erroneous particle size distribution could result in an erroneous marker concentration in the sample and its particle phase. Faichney (1993) demonstrated that nonuniform distribution of markers in digesta, i.e. between liquid and particle phases, had little effect on digesta DM flow. However, this conclusion cannot be extended to a situation where marker concentration was biased within particle phase due to sampling errors. A triple-marker method (France \& Siddons, 1986), an extension of the double-marker method (Faichney, 1975b), was used to reconstitute true digesta. Omasal canal and duodenal digesta were separated into three phases (LP, SP and FP) and analysed for marker concentrations. Two of these phases (SP and FP) appeared to be homogeneous and should therefore not challenge the marker system used. In contrast, the LP phase containing more heterogeneous large particulate matter was probably more prone to sampling errors due to less uniform marker distribution. Therefore, more detailed studies on marker distribution in omasal canal digesta and potential effects of erroneous particle composition on the chemical composition of omasal canal LP phase are required.

\section{Organic matter and fibre flow}

The higher OM flow into the duodenum than the omasal canal indicated a net secretion of OM into the abomasum. Whether this conclusion is valid could not be verified with the current data since endogenous OM secretion into the alimentary tract is difficult to quantify. Punia et al. (1988) observed a 0.03 higher OM flow into the abomasum than the omasal canal, slightly lower than the 0.07 observed in the present study. Comparison of ash flows into the omasal canal and the duodenum indicated a net absorption of $298 \mathrm{~g}$ minerals/d between the omasal canal and proximal duodenum, which agrees with previous observations (Punia et al. 1988). However, this is not a true estimate of mineral absorption, because it is underestimated by the extent of abomasal secretion of minerals. Omasal absorption of $\mathrm{Na}$ and $\mathrm{K}$ and secretion of $\mathrm{Cl}^{-}$ions have been observed in sheep and goats (Engelhardt \& Hauffe, 1975).
The large decrease in NDF flow between the omasal canal and duodenum $(302 \mathrm{~g} / \mathrm{d})$ indicated an important role of the omasum in total NDF digestion. Furthermore, NDF flow decreased much less $(123 \mathrm{~g} / \mathrm{d})$ as digesta passed from the duodenum through the lower tract. This suggests that more NDF was digested in the omasum than in the intestines. Another possible explanation for the large proportion of NDF digested in the omasum is that the sample contained particles which, under normal conditions, are incapable of escaping the reticulum. Reticular contractions and potential backflow from the omasum discriminate on the basis of particle length and specific gravity which particles are capable of leaving the rumen (Lechner-Doll et al. 1991; Kaske \& Midasch, 1997). Particles with a low probability of escaping the rumen are likely to contain more digestible matter than particles with a high probability of leaving the rumen (Sutherland, 1988). In the present experiment, the omasal sampling device was located very close to or at the reticulo-omasal orifice, so that light particles close to this area during a reticular contraction may have been included in the sample, leading to unrepresentative sampling. This type of error cannot be ameliorated by any marker method. However, Huhtanen et al. (1997) observed no differences in particle size distribution between omasal canal and faecal samples. Similar particle size distributions suggest that errors associated with particle composition of omasal canal samples are relatively minor.

Smith (1984) speculated that the proportion of digestible fibre fermented in the omasum could be about 0.10 in bovines, which is slightly higher than the 0.07 currently reported. Assuming a $0.07 / \mathrm{h}$ digestion rate of potentially digestible NDF (Huhtanen \& Jaakkola, 1993) a mean omasal retention time of $3.5 \mathrm{~h}$ would have been required for the digestion of $300 \mathrm{~g} \mathrm{NDF} / \mathrm{d}$. In a slaughter study (Mäkelä, 1956), the lowest omasal mean retention time of lignin, estimated for a cow with the highest hay intake $(10.7 \mathrm{~kg} \mathrm{DM} / \mathrm{d})$, was $6 \mathrm{~h}$. Compared with the present study a similar or slightly greater role for the post-duodenal tract in total NDF digestion has been observed in bulls: 0.04 (Khalili \& Huhtanen, 1991) and 0.08 (Tesfa, 1993) and non-lactating cows: 0.05 (Vanhatalo et al. 1992). In dairy cows a smaller contribution of the intestines to total fibre digestion appears justified due to low retention times (Poore et al. 1991). In addition, abomasal conditions may induce a lag effect on post-abomasal cell-wall digestion. In contrast, no lag effect is likely to precede omasal cell-wall digestion.

Digestion of NDF-associated protein $(\mathrm{NDF}-\mathrm{N} \times 6.25)$ was disproportionally high between the reticulum and the duodenum (0.43), compared with that of the rumen (0.44) and post-duodenal tract $(0 \cdot 12)$. The proportion of NDFassociated protein digested in the omasum and abomasum $(0.43)$ as a proportion of total digestion was much higher than the proportion of protein-free hemicellulose $(0.06)$ or ADF (0.06) digested in these organs. These findings are consistent with those from mobile bag studies, which have indicated that post-ruminal disappearance of NDF-N is considerably greater than that of hemicellulose or cellulose (Vanhatalo et al. 1996; Huhtanen \& Vanhatalo, 1997). Susceptibility of NDF-N to post-ruminal digestion might be due to acid hydrolysis of linkages between protein and cell walls rather than enzymic digestion. 


\section{Nitrogen}

The site used to harvest the bacterial samples to assess the bacterial purine : $\mathrm{N}$ ratio had a clear impact on microbial and dietary NAN flows. Our procedure for bacterial sample preparation involved an attempt to detach particle-adherent bacteria. The degree of detachment was not verified but it is likely to have been incomplete (Craig et al. 1987). A deficiency of large particles in omasal canal digesta samples would promote a further decrease of the relative proportion of particle-associated bacteria in omasal canal bacterial samples. Since fluid-associated bacteria may have a higher purine: $\mathrm{N}$ ratio than particle-associated bacteria (Cecava et al. 1990; Perez et al. 1996b, 1997), a low recovery of particle-associated bacteria would result in an underestimate of microbial NAN flow. Ruminal bacterial samples had consistently higher $(P<0.05)$ purine $\mathrm{N}$ values than omasal canal or duodenal samples, which probably reflects a smaller proportion of particles in ruminal than omasal canal samples obtained by our procedures. Moreover, as duodenal digesta samples appeared to contain more particulate matter than omasal canal samples, the purine: $\mathrm{N}$ value was lower $(P<0.05)$ for duodenal than omasal canal bacteria. An alternative explanation for this difference is that duodenal bacterial composition was modified due to abomasal digestion (Dobson et al. 1984), which has led some scientists to discourage the use of bacteria harvested from the abomasum or duodenum (Titgemeyer, 1997).

Using ${ }^{35} \mathrm{~S}$ or ${ }^{15} \mathrm{~N}$ as microbial markers Siddons et al. (1982) found lower microbial NAN flow into the duodenum when bacterial samples were collected from the rumen compared with the duodenum. Perez et al. (1996a) observed lower microbial flows into the duodenum estimated using purine bases compared with ${ }^{15} \mathrm{~N}$. In both experiments differences were attributed to unrepresentative sampling of bacteria leaving the rumen.

Use of bacterial purine: $\mathrm{N}$ ratios to calculate microbial NAN flow underestimates this value due to the contribution of protozoal NAN, since protozoa have been reported to have a considerably lower purine content than bacteria (Firkins et al. 1987). In cattle, estimates of the protozoal contribution to microbial NAN flow have varied from 0.2 to 0.5 (Firkins et al. 1987; Steinhour et al. 1982; Punia et al. 1988; Punia \& Leibholz, 1994). Therefore, assuming that the protozoal purine: $\mathrm{N}$ value was 0.55 of that for bacteria (Firkins et al. 1987) and the proportion of protozoa in microbial NAN was between 0.1 and 0.3 of microbial NAN flow, this value would have been underestimated by between 0.05 and 0.14 in this experiment due to the exclusion of protozoa.

Ruminal degradation of RNA and purine bases is often assumed to be complete (McAllan \& Smith, 1973). However, Perez et al. (1996b) estimated that the proportion of purines escaping rumen degradation ranged between 0.02 and 0.22 for a range of feedstuffs assuming a $0 \cdot 02 / \mathrm{h}$ outflow rate. This would be a compensating error in our estimates but may have also masked true differences in microbial flow between diets due to variation in dietary purine escape.

Rather than trying to draw conclusions about the most reliable bacterial sampling site, a more suitable approach to measure microbial NAN flow out of the rumen should be advocated. First, the contribution of protozoa to $\mathrm{N}$ leaving the rumen should be quantified. Second, since using mixed populations of liquid- and solid-associated bacteria may not be an adequate approach due to difficulties in quantitative detachment of particle-associated bacteria (Craig et al. 1987; Cecava et al. 1990), the purine concentrations of fluid- and particle-associated bacteria should be determined separately. DM flow in liquid and solid phases can be estimated separately if an appropriate double- or triplemarker method is used. If purine concentrations are also separately analysed for liquid and solid phases then the respective bacterial purine $: \mathrm{N}$ ratios can be used to calculate microbial NAN flow in both phases separately. Faichney et al. (1997) used this type of procedure in combination with $\left[{ }^{14} \mathrm{C}\right]$ choline-labelled protozoa and ${ }^{15} \mathrm{~N}$ to determine duodenal flows of protozoa, liquid-associated bacteria and solids-associated bacteria.

Total NAN flows were similar into the omasum and duodenum (319 v. $324 \mathrm{~g} / \mathrm{d})$. These values agree with those of Punia et al. (1988), who observed similar NAN flows into the omasum and abomasum $(60 v .63 \mathrm{~g} / \mathrm{d})$ in $300 \mathrm{~kg}$ heifers. Similar total NAN flows for the sampling sites despite lower endogenous NAN flows reported into the omasum than into the duodenum (Ørskov et al. 1986; Hart \& Leibholz, 1990) might indicate NAN absorption from the omasum, which is consistent with indirect evidence indicating peptide absorption from the omasum (Matthews et al. 1996).

Slightly higher microbial NAN flow into the omasum than the duodenum is in contrast with a slightly higher bacterial $\mathrm{N}$ flow into the duodenum than from the rumen in sheep (12.6 v. $13.4 \mathrm{~g} / \mathrm{d}$; Faichney et al. 1997). Since some fibre fermentation seemed to occur in the omasum, some microbial synthesis might be expected. The extent of dietary purine digestion was not estimated but some purines may have been digested in the omasum thereby decreasing duodenal purine flow. If duodenal microbial NAN flow were calculated using duodenal bacterial composition, omasal microbial NAN flow would be lower than duodenal flow (186 v. $195 \mathrm{~g} / \mathrm{d}$ respectively). However, this procedure assumes that no bacterial lysis occurred in the abomasum and that the different proportion of particles in digesta samples did not affect the bacterial composition but that differences were derived from microbial synthesis in the omasum. Similar efficiencies of microbial $\mathrm{N}$ synthesis estimated in the omasum and duodenum suggest that omasal $\mathrm{N}$ metabolism had a small effect on total microbial synthesis. Efficiencies observed in the present study were within the range estimated to be reasonable for high-quality diets (20-25 g N/kg OM truly fermented; Titgemeyer, 1997).

The accuracy of calculated dietary NAN flow depends on the accuracy of microbial NAN and endogenous NAN flow. Endogenous NAN flow was estimated based on results with cattle nourished with protein-free nutrients by intragastric infusion (Ørskov et al. 1986). If calculated on a per kg live weight $^{0.75}$ basis, Hart \& Leibholz (1990) reported a similar omasal endogenous NAN flow as Ørskov et al. (1986) but an abomasal endogenous NAN flow that was 0.22 units higher. Omasal endogenous NAN flow seemed to be positively correlated to DM intake whereas abomasal flow 
appeared to be unrelated to DM intake (Hart \& Leibholz, 1990). If a duodenal endogenous NAN flow of 0.22 units higher were used, dietary NAN flow would be similar into the omasum and duodenum (123 and $121 \mathrm{~g} / \mathrm{d}, P=0 \cdot 22$ ). Since endogenous NAN flow is considerably lower into the omasum than the duodenum, a more accurate estimate of dietary NAN flow could be expected.

\section{Conclusions}

The omasal canal sampling technique provides a promising alternative to duodenal sampling as a means of investigating ruminal digestion in cattle. However, accuracy and precision of omasal canal flows are more dependent on marker techniques than duodenal flows. Omasal canal sampling enables quantification of soluble $\mathrm{N}$-fractions leaving the rumen, since abomasal degradation of microbial $\mathrm{N}$ can be avoided. Comparison of omasal canal and duodenal digesta flows indicated absorption of minerals from the omasum and $\mathrm{OM}$ secretion in the abomasum. The extent of NDF and ADF digestion appeared to be greater in the omasum than in the intestines. Whether this was an unbiased estimate cannot be elucidated in the present trial. The role of the omasum in NDF digestion requires further evaluation. Differences between $\mathrm{N}$ fraction flows entering the omasal canal and duodenum were non-significant.

\section{Acknowledgements}

The authors wish to thank Mr Aaro Hakkarainen for building the omasal sampling device, Mrs Aino Matilainen and her staff for care of the animals and Mr Vesa Toivonen and his staff for the laboratory analysis.

\section{References}

Ahvenjärvi S, Vanhatalo A, Huhtanen P \& Varvikko T (1999) Effects of supplementation of a grass silage and barley diet with urea, rapeseed meal and heat-moisture treated rapeseed cake on omasal digesta flow and milk production in lactating dairy cows. Acta Agricultura Scandinavica 49, 179-189.

Barker SB \& Summerson WH (1941) The colorimetric determination of lactic acid in biological material. Journal of Biological Chemistry 138, 535-554.

Cecava MJ, Merchen NR, Gay LC \& Berger LL (1990) Composition of ruminal bacteria harvested from steers as influenced by dietary energy level, feeding frequency, and isolation technique. Journal of Dairy Science 73, 2480-2488.

Craig WM, Broderick GA \& Ricker DB (1987) Quantitation of microorganisms associated with the particulate phase of ruminal ingesta. Journal of Nutrition 117, 56-62.

Dobson DE, Prager EM \& Wilson AC (1984) Stomach lysozymes of ruminants. I. Distribution and catalytic properties. Journal of Biological Chemistry 259, 11607-11616.

Engelhardt WV \& Hauffe R (1975) Role of the omasum in absorption and secretion of water and electrolytes in sheep and goats. In Digestion and Metabolism in the Ruminant. Proceedings of the IV International Symposium on Ruminant Physiology, pp. 217-230 [IW McDonald and ACI Warner, editors]. Sydney: The University of New England Publishing Unit.

Faichney GJ (1975a) The effect of formaldehyde treatment of a concentrate diet on the passage of solute and particle markers through the gastrointestinal tract of sheep. Australian Journal of Agricultural Research 13, 319-327.

Faichney GJ (1975b) The use of markers to partition digestion within the gastrointestinal tract of ruminants. In Digestion and Metabolism in the Ruminant. Proceedings of the IV International Symposium on Ruminant Physiology, pp. 277-291 [IW McDonald and ACI Warner, editors]. Sydney: The University of New England Publishing Unit.

Faichney GJ (1993) Digesta flow. In Quantitative Aspects of Ruminant Digestion and Metabolism, pp. 53-85 [JM Forbes and $\mathrm{J}$ France, editors]. Wallingford: CAB International.

Faichney GJ, Poncet C, Lassalas B, Jouany JP, Millet L, Doré J \& Brownlee AG (1997) Effect of concentrates in a hay diet on the contribution of anaerobic fungi, protozoa and bacteria to nitrogen in rumen and duodenal digesta in sheep. Animal Feed Science and Technology 64, 193-213.

Firkins JL, Berger LL, Merchen NR, Fahey GC Jr \& Mulvaney RL (1987) Ruminal nitrogen metabolism in steers as affected by feed intake and dietary urea concentration. Journal of Dairy Science 70, 2302-2311.

France J \& Siddons RC (1986) Determination of digesta flow by continuous marker infusion. Journal of Theoretical Biology 121, 105-119.

Harmon DL \& Richards CJ (1997) Considerations for gastrointestinal cannulations in ruminants. Journal of Animal Science 75, $2248-2255$.

Hart FJ \& Leibholz J (1990) A note on the flow of endogenous protein to the omasum and abomasum of steers. Animal Production 51, 217-219.

Huhtanen PJ, Blauwiekel R \& Saastamoinen I (1998) Effects of intraruminal infusions of propionate and butyrate with two different protein supplements on milk production and blood metabolites in dairy cows receiving grass silage-based diet. Journal of the Science of Food and Agriculture 77, 213222.

Huhtanen P, Brotz PG \& Satter LD (1997) Omasal sampling technique for assessing fermentative digestion in the forestomach of dairy cows. Journal of Animal Science 75, 1380-1392.

Huhtanen P \& Jaakkola S (1993) The effects of the forage preservation method and the proportion of concentrate on digestion of cell wall carbohydrates and rumen digesta pool size in cattle. Grass and Forage Science 48, 155-165.

Huhtanen P \& Kukkonen U (1995) Comparison of methods, markers, sampling sites and models for estimating digesta passage kinetics in cattle fed at two levels of intake. Animal Feed Science and Technology 52, 141-158.

Huhtanen P \& Vanhatalo A (1997) Ruminal and total plant cellwall digestibility estimated by a combined in situ method utilizing mathematical models. British Journal of Nutrition 78, 583-598.

Huida L, Väätäinen H \& Lampila M (1986) Comparison of dry matter contents in grass silages as determined by oven drying and gas chromatographic water analysis. Annales Agriculturae Fenniae 25, 215-230.

Kaske M \& Midasch A (1997) Effects of experimentally-impaired reticular contractions on digesta passage in sheep. British Journal of Nutrition 78, 97-110.

Khalili H \& Huhtanen P (1991) Sucrose supplements in cattle given grass silage-based diet. 2. Digestion of cell wall carbohydrates. Animal Feed Science and Technology 33, 263-273.

Lechner-Doll M, Kaske M \& Engelhardt WV (1991) Factors affecting the mean retention time of particles in the forestomach of ruminants and camelids. In Physiological Aspects of Digestion and Metabolism in Ruminants: Proceedings of the Seventh International Symposium on Ruminant Physiology, pp. 455-482 [T Tsuda, Y Sasaki and R Kawashima, editors]. San Diego, CA: Academic Press. 
Licitra G, Hernandez TM \& Van Soest PJ (1996) Standardization of procedures for nitrogen fractionation of ruminant feeds. Animal Feed Science and Technology 57, 347-358.

McAllan AB \& Smith RH (1973) Degradation of nucleic acids in the rumen. British Journal of Nutrition 29, 331-345.

McCullough H (1967) The determination of ammonia in whole blood by direct colorimetric method. Clinica Chimica Acta 17, 297-304.

Mäkelä A (1956) Studies on the question of bulk in the nutrition of farm animals with special reference to cattle. Acta Agralia Fennica 85, 1-130.

Matthews JC, Wong EA, Bender PK, Bloomquist JR \& Webb KE Jr (1996) Demonstration and characterization of dipeptide transport system activity in sheep omasal epithelium by expression of mRNA in Xenopus laevis oocytes. Journal of Animal Science 74, 1720-1727.

Ørskov ER, Macleod NA \& Kyle DJ (1986) Flow of nitrogen from the rumen and abomasum in cattle and sheep given protein-free nutrients by intragastric infusion. British Journal of Nutrition 56, 241-248.

Perez JF, Balcells J, Guada JA \& Castrillo C (1996a) Determination of rumen microbial-nitrogen production in sheep: a comparison of urinary purine excretion with methods using ${ }^{15} \mathrm{~N}$ and purine bases as markers of microbial-nitrogen entering the duodenum. British Journal of Nutrition 75, 699-709.

Perez JF, Balcells J, Guada JA \& Castrillo C (1997) Rumen microbial production estimated either from urinary purine derivative excretion or from direct measurements of ${ }^{15} \mathrm{~N}$ and purine bases as microbial markers: effect of protein source and rumen bacteria isolates. Animal Science 65, 225-236.

Perez JF, Rodriguez CA, Gonzalez J, Balcells J \& Guada JA (1996b) Contribution of dietary purine bases to duodenal digesta in sheep. In situ studies of purine degradability corrected for microbial contamination. Animal Feed Science and Technology 62, 251-262.

Poore MH, Moore JA, Eck TP \& Swingle RS (1991) Influence of passage model, sampling site, and marker dosing time on passage of rare earth-labeled grain through Holstein cows. Journal of Animal Science 69, 2646-2654.

Punia BS \& Leibholz J (1994) Effect of level of intake of kikuyu (Pennisetum clandestinum) grass hay on the flow of protozoal nitrogen to the omasum of cattle. Animal Feed Science and Technology 47, 77-87.

Punia BS, Leibholz J \& Faichney GJ (1988) Effects of level of intake and urea supplementation of alkali-treated straw on protozoal and bacterial nitrogen synthesis in the rumen and partition of digestion in cattle. Australian Journal of Agricultural Research 39, 1181-1194.

Robertson JB \& Van Soest PJ (1981) The detergent system of analysis and its application to human foods. In The Analysis of
Dietary Fiber in Food, pp. 123-158 [WPT James and O Theander, editors]. New York, NY: Marcel Dekker.

Siddons RC, Beever DE \& Nolan JV (1982) A comparison of methods for the estimation of microbial nitrogen in duodenal digesta of sheep. British Journal of Nutrition 48, 377-389.

Siddons RC, Paradine J, Beever DE \& Cornell PR (1985) Ytterbium acetate as a particulate-phase digesta-flow marker. British Journal of Nutrition 54, 509-519.

Smith RH (1984) Microbial activity in the omasum. Proceedings of the Nutrition Society 43, 63-68.

Somogyi M (1945) A new reagent for the determination of sugars. Journal of Biological Chemistry 160, 61-68.

Steinhour WH, Stokes MR, Clark JH, Rogers JA, Davis CL \& Nelson DR (1982) Estimation of the proportion of non-ammonianitrogen reaching the lower gut of the ruminant derived from bacterial and protozoal nitrogen. British Journal of Nutrition $\mathbf{4 8}$, 417-431.

Sutherland TM (1988) Particle separation in the forestomachs of sheep. In Aspects of Digestive Physiology in Ruminants, pp. 4373 [A Dobson and MJ Dobson, editors]. Ithaca, NY: Cornell University Press.

Tesfa AT (1993) Effects of rape-seed oil supplementation on digestion, microbial protein synthesis and duodenal microbial amino acid composition in ruminants. Animal Feed Science and Technology 41, 313-328.

Titgemeyer EC (1997) Design and interpretation of nutrient digestion studies. Journal of Animal Science 75, 2235-2247.

Udén P, Colucci PE \& Van Soest PJ (1980) Investigation of chromium, cerium and cobalt as markers in digesta. Rate of passage studies. Journal of the Science of Food and Agriculture 31, 625-632.

Vanhatalo A, Dakowski P \& Huhtanen P (1996) Effects of stage of growth and duration of rumen incubation time on intestinal digestibility of rumen-undegradable nitrogen of grass by mobile-bag method in cows. Acta Agricultura Scandinavica, Section A, Animal Science 46, 1-10.

Vanhatalo A, Varvikko T \& Aronen I (1992) The effect of type of additive on rumen fermentation and digestion of grass silage in cattle. Agricultural Science in Finland 1, 163-175.

Van Soest PJ, Robertson JB \& Lewis BA (1991) Methods for dietary fiber, neutral detergent fiber and nonstarch polysaccharides in relation to animal nutrition. Journal of Dairy Science 74, 3583-3597.

Williams CH, David D \& Riismaa O (1962) The determination of chromic oxide in faeces samples by atomic absorption spectrometry. Journal of Agricultural Science, Cambridge 59, 381385.

Zinn RA \& Owens FN (1986) A rapid procedure for purine measurement and its use for estimating net ruminal protein synthesis. Canadian Journal of Animal Science 66, 157-166. 